\title{
Anti-Radicalism Education for Millenial Generations in Islamic Higher Education
}

\section{Zamroni $^{1}$}

DOI : $10.35445 /$ alishlah.v13i3.818

\begin{tabular}{|c|c|}
\hline Article Info & Abstract \\
\hline $\begin{array}{l}\text { Keywords: } \\
\text { Anti-radicalism; } \\
\text { millennial students; } \\
\text { higher education }\end{array}$ & $\begin{array}{l}\text { This study aims to analyse and understand the importance of anti-radicalism } \\
\text { education provided to millennial generation students in East Kalimantan. This } \\
\text { study uses a qualitative case study approach. The researcher tries to reveal the } \\
\text { reality ofthe meaning in the anti-radicalism education field at three universities } \\
\text { in East Kalimantan, including IAIN Samarinda, STIT Balikpapan, and STAI } \\
\text { Sangatta East Kutai. The researcher conducted interviews, observations, and } \\
\text { documentation to obtain information about the themes studied. Data analysis } \\
\text { was carried out circularly, starting with data presentation, data reduction, and } \\
\text { concluding. The results show that anti-radicalism education is very much needed } \\
\text { in East Kalimantan. Considering that the area has good potential resources, the } \\
\text { community is very heterogeneous. The area is used as a hiding place for } \\
\text { terrorists, and the anti-radicalism education aims to neutralise the ideas of } \\
\text { radicalism thatcontinue to grow. }\end{array}$ \\
\hline
\end{tabular}

Kata kunci:

Pendidikan anti

radikalisme;

mahasiswa millennial;

Perguruantinggi

\begin{abstract}
Abstrak
Penelitian bertujuan untuk menganalisis dan memahami tentang pentingnya pendidikan anti radikalisme vang diberikan kepada mahasiswa millennial di Kalimantan Timur. Penelitian ini menggunakan pendekatan kualitatif jenis studi kasus, di mana peneliti berusaha untuk mengungkap realitas makna yang terjadi di lapangan tentang pendidikan anti radikalisme pada tiga perguruan tinggi di Kalimantan Timur, yang meliputi IAIN Samarinda, STIT Balikpapan dan STAI Sangatta Kutai Timur. Peneliti melakukan interview, observasi dan dokumentasi untuk mendapatkan informasi tentang tema yang dikaji. Analisis datanya dilakukan secara sirkuler, yang dimulai dari penyajian data, reduksi data dan penarikan kesimpulan. Hasil penelitian menuniukkan bahwa pendidikan anti radikalisme sangat diperlukan di Kalimantan Timur mengingat daerah tersebut memiliki potensi sumber daya yang menjanjikan, masyaraktnya yang sangat heterogen, daerah tersebut dijadikan sebagai tempat persembunvian para teroris, dan pendidikan anti radikalisme tersebut ditujukan untuk menetralisir pemikiran radikalisme yang terus berkembang.
\end{abstract}

${ }^{1}$ Un iv ersitas Islam Negeri Sultan Aji Muhammad Idris, Samarinda, Indonesia

Em a il: iceisa.iainsmd18@gmail.com 


\section{INTRODUCTION}

Radicalism is often considered an activity that leads to violence in practice, while fundamentalism is understood as a radical struggle (Zuhdi, 2010). Radicalism, in this case, refers to acts of violence shown by certain groups by carrying religious legitimacy in them. The radicalisation of the movement led by certain religions is a form of the strong desire of religious adherents to practice their spiritual teachings (Rantung, 2018).

Radicalism is a religious movement that shows a conservative attitude, uses violence in its religious activities, justifies all kinds of ways to manifest its beliefs (Khalis, 2019). They tend to commit acts of violence, terror, which causes people to become restless (Juergensmeyer, 2002). While Islam as a religion of peace, love and rahmatan lil alamin (Dakir, 2017; Fauzi, 2019; Solikhun, 2021; Arif, 2021). Of course, this is contrary to Islam because Islamic teachings do not justify acts of violence in preaching, scaring, or creating terror and an unsafe atmosphere (Mundiri, 2011; Anwar, 2019). Radicalism aims to weaken and change the established order of life and replace it with new ideas (Hafid, 2020).

Radicalism is growing in Indonesia, along with the uncertain socio-political situation and conditions (Asrori, 2019). In practice, they tend to fight for the kaffah enforcement of Islamic law, fight for the establishment of the "khilafah Islamiyah", the establishment of the Islamic State of Indonesia, and so on. (Qomaruzzaman, 2013; Tanjung, 2018). Likewise, the organisation also varies, such as the MTA, Hizbut Tahrir Indonesia, Majlis Mujahidin Indonesian, to military styles such as Laskar Jihad and FPI (Qomaruzzaman, 2013; Tanjung, 2018).

The phenomenon of religious radicalism today is starting to thrive in several universities, especially in East Kalimantan. In reality, higher education, known as a place for nurturing students with a critical, open/inclusive, and intellectual perspective, cannot be immune to the influence of radicalism ideology (Hakim \& Ekapti, 2019). Campus becomes a soft ground for the recruitment of radicalism activists and a fertile place to sow the seeds of radicalism (Effendi et al., 2020). Public universities, in particular, became the target of operations to strengthen the movement (Basri \& Dwiningrum, 2019). Many students are trapped in radical, closed, exclusive religious activities, and it is not uncommon for many of them to disappear with family assets to participate in organisational activities (Hadziq, 2019). Likewise, Islamic religious universities did not escape the target of the radicalisation movement, resulting in significant changes in these institutions (Hakim \& Ekapti, 2019).

This movement developed due to the existence of radical groups that utilise Islamic religious higher education such as IAIN Samarinda, Sekolah Tinggi Ilmu Tarbiyah (STIT) Balikpapan, and STAI Sangatta East Kutai, which became the site of this research, as an essential medium for treading the level of social mobility, improving social status, at the same time shape one's socio-religious attitudes (Khozin, 2013; Munif, 2018). In addition, the psychological condition of students who are still unstable to be recruited. Students who participate in this activity are trying to find a future orientation that they will take, so they need the influence to facilitate the identity they are looking for (Sahri, 2016).

Today's Islamic religious universities in East Kalimantan find it challenging to cover themselves with the presence of heterogeneous and diverse prospective students. With the opening of several new and marketable study programs, Islamic universities such as IAIN Samarinda, STIT Balikpapan, and STAI Sangatta Kutai Timur were invaded by students with different backgrounds, religious, social, cultural knowledge, and so on. The friendly, polite, tolerant atmosphere, the solemnity of the spiritual touch, began to fade. At the same time, the seeds of radicalisation began to grow, which were used by several parties

Therefore, preventive efforts are needed from an early age so that the movement does not become too entrenched in religious-based universities. Higher education must play a role in preventing and eradicating religious radicalism in Indonesia as a form of commitment to stopping terrorism (Hadziq, 2019). In other words, to prevent and quell the development of religious 
radicalism, it is not enough to hang, shoot to death, and be imprisoned for life. Still, a practical approach must be taken, namely through deradicalisation activities carried out simultaneously by involving all parties.

The need for deradicalisation is caused by the danger of radicalism which must be avoided. Deradicalization is an effort to neutralise radical ideas by implementing a multi-interdisciplinary approach strategy, social, cultural, religious, economic, political, legal, for those who fall into radicalism (Rokhmad, 2012; Apriliana et al., 2017)

Research on anti-radicalism through various activities has been carried out, including; Ghifari (2017) stated that technology, the internet, and social media contributed significantly to the spread of radicalism in Indonesia. Because according to Lubis \& Siregar (2020), they will get information about radicalism through social media. Therefore, Syahputra (2020) stated that a movement was needed to fight the spread of radicalism on social media through the national ground coffee, regional coffee, social media readings, and scheduled activities to produce positive and viral content. Through this, according to FW \& Royyan (2020) and Noorhayati (2020), the social media homepage will be filled with positively charged things so that radical understanding can be sidelined.

Baharun \& Awwaliyah (2017) and Marzuki et al. (2020) said that a planned and systematic multicultural education is needed to overcome radicalism. Furthermore, Rozi (2019) said that religious radicalism could be prevented through moderate and quality Islamic education for students. According to Muqoyyidin (2013) and Badriah (2020), Islamic education with inclusivemulticultural nuances, and of course, according to Artina et al. (2021), interfaith solid youth leadership is needed to counter this radicalism. Sudjito \& Muhaimin (2018), Rengkung \& Lengkong (2020), Siagian (2020), Deti \& Dewi (2021) say that it is also necessary to revitalise understanding and cultivate Pancasila values in everyday life. It has purposes to deal with cases of intolerance and prevent the growth and development of radical ideas that are very dangerous and threaten the integrity of the Unitary State of the Republic of Indonesia and the unity of Indonesia.

García \& Antonio (2019), Mundiri et al. (2020), Syatar (2020), Kasdi et al. (2020) said that religious thought moderation and revitalisation in universities are needed to overcome radicalism. So, according to Kisbiyanto (2016) and Ekawati (2018), it is necessary to revamp the curriculum system in education that effectively prevents radicalism. In addition, according to Llorent-Bedmar et al. (2020), training and coaching for teachers are needed in anticipating acts of violence from radicalism.

Based on these studies, this research has a unique and novelty related to the contestation of deradicalisation discourse launched by the government through strengthening educational institutions in universities, such as IAIN Samarinda, STIT Balikpapan, and STAI Sangatta East Kutai, which became the site of this research. Along with the development of globalisation, the discourse of deradicalisation towards students as the millennial generation is experiencing enormous challenges, especially in dealing with students' heterogeneous character, unstable psychology, socio-political developments, and so on. This is because the deradicalisation program BNPT has spearheaded by cooperating with universities as partners seems to be still in effective in tackling radicalism.

This fact is also exacerbated by the existence of "commodification of deradicalisation discourse," meaning that deradicalisation activities carried out by universities are only used as "mega projects" to disburse funds from the centre for personal and group benefits. On the other hand, the discourse of deradicalisation is used as a branding and imaging medium through which universities can introduce their institutions to the public. The anti-radicalism or deradicalisation program, which has very complex challenges, runs less than optimally, is less substantive, and begins to come out of the spirit of real anti-radicalism or deradicalisation education activities. Hence, it is necessary to reformulate deradicalisation in universities. This research is focused on 
the reasons why anti-radicalism / deradicalisation education needs to be carried out on students at East Kalimantan higher education

\section{METHODS}

This study uses a qualitative case study approach to get an overview of anti-radicalism education conducted by Islamic religious universities in East Kalimantan to their students to prevent the spread of radicalism. The research sites are IAIN Samarinda, STIT Balikpapan and STAI Sangatta Kutai Timur as representatives of universities in East Kalimantan.

The researchers conducted interviews with ten informants consisting of lecturers and students, observations on various activities, and documentation to obtain information about the themes to be studied. Some of the data is analysed in stages, starting with presenting all existing data, then continued with data reduction concerning the research theme raised, and ending with the study's conclusion as a finding of this study.

\section{FINDINGS AND DISCUSSION}

The results showed that the reasons for the need for anti-radicalism or deradicalisation education at universities in East Kalimantan, which included IAIN Samarinda, STIT Balikpapan, and STAI Sangatta East Kutai as representatives of Islamic universities in East Kalimantan were;

\section{Promising Resource Potential}

East Kalimantan is listed as the most extensive province after Papua. East Kalimantan has the potential for abundant natural resources. Most of the proceeds from these natural resources are sent abroad. Therefore East Kalimantan is one of the country's leading foreign exchange earners, specialising in mining and forestry. East Kalimantan's mining products include oil, natural gas, coal, agriculture, tourism, and processing industries. This excellent resource then became one of the reasons for the importance of Deradicalization in East Kalimantan.

With such extraordinary natural potential, it will be straightforward for a person or group to use it as an excuse to enter the area or interact with people in East Kalimantan. This was conveyed by MI, the leader of IAIN Samarinda:

"One of the strong reasons why anti-radical education needs to be given to students is because East Kalimantan has such promising natural resources. Moreover, the result is that they are exported to foreign countries, automatically interacting with people outside (East Kalimantan) is very difficult to avoid, maybe even then making this the reason behind the concept of radicalisation that will be shown in the East Kalimantan region”.

KAS also conveyed the same thing as a lecturer at ST IT Balikpapan:

"anti-radicalism education needs to be instilled in students from an early age because East Kalimantan has relatively large and promising resources, and it can be a boomerangforthis province."

As a lecturer at STAI Sangatta East Kutai, AS said that the spread of radical ideas that leads to terrorism, such as the ISIS armed group, needs to be anticipated. East Kalimantan is a conducive area; geographically, it is directly adjacent to several neighbouring countries.

The informant's statement shows that the resource factor owned by the region can have a significant impact on the spread of radicalism in the East Kalimantan region. Therefore, radicalism or deradicalisation education needs to be carried out from an early age to students as the millennial generation in universities, hoping that students of the nation's next-generation have an inclusive, moderate, and multicultural perspective.

\section{People's Heterogeneity}

East Kalimantan is an area that is very vulnerable to being influenced by teachings and terrorist and radical groups, considering that students in universities in East Kalimantan are very 
heterogeneous. They consist of several tribes, languages, customs, and beliefs. This is as stated by MM, who said that students in East Kalimantan are very heterogeneous. They consist of many tribes, languages, religions, and cultures entering into radical understanding. Therefore, multiculturalism education is needed from an early age so that students avoid misleading and exclusive deals.

The multicultural and heterogeneous social conditions of the people in East Kalimantan are caused by the indigenous people of East Kalimantan and immigrants. They come from several areas and settle there. RSA said that the heterogeneity of the people's social life in East Kalimantan was due to many migrants from several regions and settled here, such as the Javanese and Bugis. They could more easily accept new things or also meet newcomers. This fact can then become an opportunity for radical groups to carry out their actions.

The informant's statement shows that the arrival of the Javanese and Bugis people has resulted in an unequal proportion of the number of indigenous people, namely the Dayak and Banjar tribes and the immigrant communities. This imbalance will make East Kalimantan an area that is easily spread by radicalism so that deradicalisation is very much needed for students in higher education. AM said that the importance of deradicalisation is instilled in students from an early age because the population in East Kalimantan is inhabited by the majority of immigrants and students in several campuses spread across this province. Of the newcomers, we do not know their intentions one by one. It could be that one of them has a desire to spread radical ideas. Not accusing but better be careful.

This statement is very reasonable because the community and immigrant students have different orientations in their lectures, especially when faced with senior students who invite them to participate in various activities that lead to radicalised movements. Its activities are planned, systematic and massive in spreading its radicalism movement. And this must be watched out for by all leaders and policymakers in Islamic universities

\section{The hideout of the terrorists}

As the second-largest province in Indonesia, East Kalimantan is vulnerable to becoming a hideout for terrorists. Incredibly geographically close to neighbouring countries. This is evidenced by the number of terrorist actors caught in East Kalimantan. KW said that the East Kalimantan region is often used as a terrorist hideout because of its strategic geographical location. Moreover, there have been several times that radical actors have been found in this area. Of course, this threatens East Kalimantan from terrorist attacks because it is used as a hiding place from police pursuit.

Although famous for its heterogeneous social life, East Kalimantan is a peaceful province far from radical issues and conflicts. This is also the reason why terrorists make this area a hiding place. LA stated an area that is always peaceful, so the terrorists took advantage of that label and hid in this area. They thought that the police would not know their tracks by hiding in this area, but they were finally caught thanks to the solid cooperation between the community and the security forces.

The province of East Kalimantan was used as a hideout for terrorists because this province was a place for foreigners to pass. IA said that East Kalimantan was used as a hiding place for theorists due to geographical factors, where this area became a place for foreign citizens to pass. This shows that radicals are looking for a safe and comfortable position to hide and spread their ideas to the local community. Likewise, students become easy targets in several universities because they are considered unstable people in determining the direction of their lives. Therefore, considering East Kalimantan as a target and hiding place for terrorists, universities must be careful in carrying out the Tri Dharma activities of higher education so that their students are safe from the onslaught of radical ideologies that are starting to target students. 


\section{Neutralising Thoughts of Radicalism and Extremism}

Deradicalization is one of the programs that Islamic religious universities must carry out to tackle radicalism in East Kalimantan. This is because the deradicalisation carried out can and can neutralise radicalism thoughts among students. EM said that the East Kalimantan community is a group of people with a high level of multiculturalism. This is very vulnerable to radical ideas and does not even rule out being one of the drivers of these revolutionary ideas. Therefore, deradicalisation is a strategic and practical step in neutralising extreme understanding among students. Through this deradicalisation activity, it is hoped that students will be wiser in sorting and choosing information or knowledge that is radical or not. With this understanding, they will be less likely to be attacked by revolutionary ideas.

Universities in East Kalimantan are higher education institutions that have a role in shaping the character and behaviour of each student. Higher education functions as an educational medium in developing knowledge and being the frontline in fighting radicalism that threatens the existence of state ideology. AS said that deradicalisation is essential for all circles, especially for students. The students who are suspected of being easy targets by radicals can neutralise the information and knowledge they have acquired, whether this information is obtained during class learning when they join an organisation or wherever they are, considering that students are student figures who have complete access to the material. MI said that the radical movement had filled many universities, such as students, lecturers, staff, and leadership. If the lecturers have an extreme understanding, the learning process will more or less lead to the radicalisation and detribalisation of their students. This is, of course, very dangerous if left unchecked. Therefore, it is necessary to deradicalise to be wiser in thinking and act early in higher education.

Some of these statements show that the danger of radicalism among students as the millennial generation is very concerning. The millennial generation embedded in these students is a generation that is currently around 15-34 years old. They spend much time on digital media, so information technology strongly influences their daily behaviour (Pratiwi \& Asyarotin, 2019). This generation also often carries out online activities to fulfil their daily needs, such as online shopping, online consultations, online discussions, and so on (Syahputra, 2020; Fahyuni et al., 2020).

The hallmark of this millennial generation is its unique characteristics. The character of each individual is determined by when and where they were born and raised, their family's social strata, and their economy. This generation's communication model is more comprehensive than the previous generation; they actively use social media because their lives are affected by information and communication technology developments (Fauzi et al., 2018; Bustamin et al., 2020). Given the characteristics and characteristics of the millennial generation, it is essential to provide anti-radicalism education early on to university students to avoid exposure to radicalism and extremism, which are very dangerous for their personalities, thoughts, and attitudes in their daily actions. The seeding of radicalism ideology among students has taken place through various conventional and modern channels, no longer through direct face-to-face forums but through selfroutinisation by utilising information and technology tools. Therefore, anti-radicalism education is intended so that students have broad insight into their religion, understand the existence of plurality, are moderate-minded, which are shown through their thoughts, attitudes, and actions in their daily lives.

Society in East Kalimantan cannot be separated from the heterogeneous and plural label; perhaps it can be understood that there is no singularity of national and state life regarding ethnicity or race. With this statement, the possibility of showing homogeneity in culture or other matters is closed. A plural and heterogeneous society condition becomes understood as a gift and colour in life (Ali, 2017). There are inevitably differences in plurals and differences in intensity regarding their diversity (Kesuma, 2017).

The people of East Kalimantan, which are plural and heterogeneous in terms of gender, race, ethnicity, or duration of their culture, are historical facts that cannot be denied. This is 
because the number of indigenous people is less than the number of immigrants. East Kalimantan is an area that is very vulnerable to being influenced by the teachings and groups of terrorists and radicals because the population is multicultural and plural. This later became one of the reasons for the need for deradicalisation actions or programs in East Kalimantan. The goal is as a form of vigilance or caution from radicalisation attacks.

The meeting of the community with radical understanding is not something that exists by itself. However, radicalism exists because of the communication process with several extreme networks outside the region (Mahardika et al., 2020). Thus, the radical movements that have lived so far are trying to make changes by recruiting them as influential circles. In this way, there will be an impression that ordinary people only embrace radicalism and will fade by itself.

With the various potentials possessed by the region, it will be straightforward for a person or group of people to use that as an excuse to enter the area or interact with people in East Kalimantan. Radical groups can then utilise this potential in infiltrating their teachings with various motives. This could be one of the reasons for the need to promote deradicalisation in East Kalimantan as a form of vigilance against things that smell like radicalisation (Fay, 1967).

This understanding of radicalism develops against the background of shallow religious experience in all circles, its development is supported by the immaturity of people's mindsets, and there is considerable curiosity. The whole community, including the apparatus, needs to be motivated to direct and guide the community to avoid the development of radical understanding (Tamtanus, 2018).

Crimes that begin with polluting ideology, the door of the solution must also be in the form of things or things that can neutralise this understanding. Some ways that can be done as a form of resistance to ideological pollution with extreme versions provide comparative knowledge in which people must have Islamic thinking options, especially regarding the concept of jihad and the establishment of an Islamic caliphate.

Anything related to an ideology will need a deep understanding to make it neutral in people's mindsets hoping that people will not be affected. In this case, educational institutions need to be invited to cooperate in preventing the spread of radicalism. The community must be at the forefront of avoiding forums and media for spreading extremism (Fikri, 2019). The main thing is that the party or the role of the family must be a solid defence because the ideological filter can start from the family.

In dealing with terrorism and radicalism, solidarity and willingness of all parties are needed so that the space for radicalism and terrorism becomes narrower and disappears. In the context above, the role of East Kalimantan and educational institutions in it, which is used as a hiding medium by terrorists, is vital in stopping the rate of radicalisation. Education and educational institutions are likely to be dispersers of the seeds of radicalism and, at the same time, an antidote to radical understanding (Zulfaizah, 2018; Mahardika et al., 2020).

Deradicalization carried out by universities aims to open students' horizons to be more moderate, open, and flexible-minded. They have a high awareness of differences, pluralism, and the need for mutual respect and respect for differences (Ulum \& Azhari, 2018). Through this, the potential for students who are attacked by radicalism will be smaller.

Deradicalization will narrow the space for radical groups that have infiltrated the East Kalimantan region. Therefore, educational institutions in East Kalimantan do not need to be closed; on the contrary, they must be open to various inputs, suggestions, and differences in the scope of education or the broader field. In stemming radicalism, it is necessary to have a multicultural foundation in Islamic educational institutions to build awareness of differences and respect (Mahmud \& Zamroni, 2014; Darlis, 2017; Ilyasin \& Tohet, 2020).

Deradicalization is defined as an attitude that can prevent terrorists. Also understood as a program or activity that can understand radical and neutral views carried out with a soft power 
approach (Bachtiar, 2013). Deradicalization implies breaking and stopping the spread of ideology. Deciding, in this case, can be understood as something that encourages individuals and groups who have a radical understanding to tend to change their views in social cognition (Ekawati, 2018). They can abandon radical ideas and switch to new rules and notions that are not radical, which is the goal of deradicalisation (Suprapto, 2014).

Deradicalization is a regular effort to eliminate radical ideas. At the same time, the meaning of deradicalisation of cyberspace is to influence the views of readers and users so that they are not easily deceived by radical content (Fay, 1967). Deideology is the elimination of ideology in the name of religion, and religion is not seen as a political ideology (Rokhmad, 2012). However, religion can be understood as noble values that sow the message of peace. The meaning of the implementation of deradicalisation is long-term and not in a short time. Deradicalization targets a person or group's ideology to change radical doctrines within themselves and their groups.

One of the goals and reasons for the need for deradicalisation in higher education is to neutralise radical thinking and neutralise any developments in understanding radicals that are currently still developing without knowing the source and purpose (Muqoyyidin, 2013; Munif, 2018). In addition, it is hoped that deradicalisation can reach the layers of society, especially students, to get a correct understanding of radicalism and attitudes that are considered to deviate from teachings, especially the Islamic religion (Ikhsan, 1967). Because the age of 18-40 years is the age that is targeted by radicalism and terrorism groups, and students are the most strategic targets (Fay, 1967).

\section{CONCLUSION}

Anti-radicalism education has a vital role for universities as institutions that give birth to intelligent generations prepared to advance the nation to have a good civilisation. Anti-radicalism education or deradicalisation is very much needed in several Islamic universities in East Kalimantan. Considering that the area has Promising Potential Resources, the community is very heterogeneous. The area is used as a hiding place for terrorists, and anti-radicalism education aims to neutralise the Thoughts of Radicalism and Extremism who continue to live and thrive in higher education institutions.

Anti-radicalism education needs to be instilled in students from an early age. They do not readily accept various exclusive, closed thoughts and lead to truth claims in higher education. As a form of deradicalisation education for the millennial generation, the approach must be practical, planned, and systematic to achieve the desired goals to foster critical, open, and moderate thinking. Radical new ideologies do not easily influence students. They are protected from the trap of radical activists who actively sow the seeds of radicalism in universities, with students as the primary target.

\section{REFERENCES}

Ali, Y. F. (2017). Upaya Tokoh Agama Dalam Mengembangkan Sikap Toleransi Antarumat Beragama. Untirta Civic Education Journal, 2(1), 91-112. https://doi.org/10.30870/ucej.v2i1.2804

Anwar, H. (2019). Nilai-Nilai Pendidikan Pesantren Sebagai Core Value; Dalam Menjaga Moderasi Islam Di Indonesia. Jurnal Islam Nusantara, 3(2), 495-517.

Apriliana, D. P., Raharjanti, A. I., Sulastri, A., Noviana, D., \& Nur, N. (2017). Respons Mahasiswa terhadap Kebijakan Deradikalisasi Pemerintah. Academica: Journal of Multidiciplinary Studies, 1(1), 96-109.

Arif, K. M. (2021). Islam Rahmatan Lil Alamin from Social and Cultural Perspective Islam. AlRisalah: Jurnal Studi Dan Pemikiran Islam, 12(2), 169-186. https://doi.org/10.34005/alrisalah.v12i2.1376

Artina, F., Zubair, M., \& Alqadri, B. (2021). Interfaith Youth Leadership Dalam Menangkal Radikalisme Di Ma Unwanul Falah Nw. Journal Of Community Service, 1(1). http://ijocs.rcipublisher.org/index.php/ijocs/article/view/24

Asrori, S. (2019). Mengikuti Panggilan Jihad; Argumentasi Radikalisme Dan Ekstremisme Di 
Indonesia. Aqlam: Journal of Islam and Plurality, 4(1), 118-133. http://journal.iainmanado.ac.id/index.php/AJIP/article/view/911

Bachtiar, S. A. \& H. (2013). Deradikalisasi Idelogi Gerakan Islam Transnasional Radikal. Jurnal Multikultural \& Multireligius, 12(3), 19-36.

Badriah, F. N. (2020). Pendidikan Multikultural dalam Bingkai Islam Nusantara Perspektif KH. Said Aqil Siroj. Tafaqquh: Jurnal Penelitian Dan Kajian Keislaman, 8(1), 37-51. http://library1.nida.ac.th/termpaper6/sd/2554/19755.pdf

Baharun, H., \& Awwaliyah, R. (2017). Pendidikan Multikultural dalam Menanggulangi Narasi Islamisme di Indonesia. Jurnal Pendidikan Agama Islam (Journal of Islamic Education Studies), 5(2), 1-20.

Basri, B., \& Dwiningrum, N. R. (2019). Potensi Radikalisme di Perguruan Tinggi (Studi Kasus di Politeknik Negeri Balikpapan). JSHP : Jurnal Sosial Humaniora Dan Pendidikan, 3(1), 84-91.https://doi.org/10.32487/jshp.v3i1.546

Bustamin, Muhammad Hizbi, Islami, Jamal Mirdad, H. B. (2020). Strengthening Muslim Millenenal Generations In Era disruption. Proceeding IAIN Batusangkar, 1(1), 83-94.

Dakir, D. (2017). Pengelolaan Budaya Inklusif Berbasis Nilai Belom Bahadat Pada Huma Betang dan Transformasi Sosial Masyarakat Dayak Kalimantan Tengah. Religió: Jurnal Studi Agama-Agama, 7(1), 28-54.https://doi.org/10.15642/religio.v7i1.707

Darlis. (2017). Mengusung Moderasi Islam di Tengah Masyarakat Multikultural. Rausyan Fikr, 13(2), 225-255. https://doi.org/10.1017/CBO9781107415324.004

Deti, S., \& Dewi, D. A. (2021). Pengimplementasian Nilai Nilai Pancasila Untuk Mencegahnya Radikalisme Di Indonesia. Edumaspul: Jurnal Pendidikan, 5(1), 557-564.

Effendi, H., Aisyah, S., Muspardi, \& Muslim. (2020). Analisis Kebutuhan Pengembangan Buku Ajar dalam Model Pembelajaran Sejarah Islam Berbasis Kebhinnekaan (PSI-BK) sebagai Daya Tangkal Radikalisme di Perguruan Tinggi. Jurnal Education and Development Institut, 8(3), 330-334.

Ekawati, M. S. dan K. S. (2018). Moderasi Kurikulum Perguruan Tinggi Islam dalam Deradikalisasi $\begin{array}{lllll}\text { Agama di Indonesia. } & \text { I39-178. }\end{array}$ http://istiqro.kemenag.go.id/index.php/istiqro/article/view/97/82

Fauzi, A. (2019). Epistemologi Pendidikan Islam Rahmatan Lil 'Alamin di Era Revolusi Industri 4.0; Sebuah Kajian Paradigmatik. Edureligia: Jurnal Pendidikan Agama Islam, 3(2), 9210o.http://jurnaljpi.com/index.php/JPI/article/view/28

Fauzi, A., BR, R., \& Baharun, H. (2018). Analysis Study of Parental Choice of Education in The Millenial Era. Nadwa : Jurnal Pendidikan Islam, 12(51), 311-330.

Fay, D. L. (1967). 済無No Title No Title No Title. Angewandte Chemie International Edition, 6(11), 951-952.

Fikri, M. (2019). Moderasi Pendidikan Pesantren Berbasis Perjumpaan dalam Bayang-Bayang Radikalisme di Lombok Nusa Tenggara Barat. Komunike, 11(2), 22-37.

FW, N., \& Royyan, M. (2020). Kontribusi Young Interfaith Peacemaker Community (YIPC) dalam Menyebarkan Narasi Kontra Radikalisme. Al-Mada: Jurnal Agama, Sosial, Dan Budaya, 3(2), 128-150. https://doi.org/10.31538/almada.v3i2.644

García, R., \& Antonio, J. (2019). Islamic religious education and the plan against violent radicalisation in Spain. British Journal of Religious Education, 41(4), 412-421. https://doi.org/10.1080/01416200.2018.1484693

Ghifari, I. F. (2017). Radikalisme di Internet. Religious: Jurnal Agama Dan Lintas Budaya, 2(1), 123-134. https://doi.org/10.15575/jw.v39i1.575

Hadziq, A. (2019). Nasionalisme Organisasi Mahasiswa Islam dalam Menangkal Radikalisme di Institut Agama Islam Negeri (IAIN) Surakarta. Jurnal Pendidikan Agama Islam AlThariqah, 4(1), 50-59. https://doi.org/10.25299/al-thariqah.2019.vol4(1).2791

Hafid, W. (2020). Geneologi Radikalisme Di Indonesia (Melacak Akar Sejarah Gerakan Radikal). Al-Tafaqquh: Journal of Islamic Law, $\quad 1(1), \quad 31$. https://doi.org/10.33096/altafaqquh.vii1.37

Hakim, L., \& Ekapti, R. F. (2019). Penguatan Pendidikan Pancasila Sebagai Jatidiri, Refleksi, Dan Tantangan Dalam Membatasi Paham Radikalisme Mahasiswa Di Perguruan Tinggi Islam Ponorogo. Muslim Heritage, 4(2). https://doi.org/10.21154/muslimheritage.v4i2.1850

Ikhsan, M. A. (1967). Al-Quran Dan Deradikalisasi Paham Keagamaan Di Perguruan Tinggi: 
Pengarusutamaan Islam Wasathiyah. Jurmal Ilmu Al Qur'an Dan Hadis, 2(2), 98-112.

Ilyasin, M., \& Tohet, M. (2020). Multicultural education in a religious life: Developing harmony among religions in southeast asia. Proceedings of the International Conference on Industrial Engineering and Operations Management, August, 3791-3801.

Juergensmeyer, M. (2002). Teror Atas Nama Tuhan: Kebangkitan Global Kekerasan Agama. Nizam Press.

Kasdi, A., Farida, U., \& Mahfud, C. (2020). Islamic Studies and Local Wisdom at PT KIN in Central Java: Opportunities, Challenges, and Prospects of Pioneering Religious Moderation in Indonesia. Hikmatuna, 6(1), 51-62.

Kesuma, T. (2017). Pola Integrasi dalam Masyarakat Majemuk (Studi Ketahanan Sosial di $\begin{array}{llll}\text { Kecamatan Kotagajah, } & \text { Lampung). } & \text { Jipsindo, } & \text { 4(2), }\end{array}$ https://doi.org/10.21831/jipsindo.v4i2.17576

Khalis, H. (2019). Kearifan Lokal Dan Radikalisme: Memperkuat Pembelajaran Pai Melalui Scientific Learning. Jurnal Islam Nusantara, 3(1), 287-306.

Kisbiyanto. (2016). Manajemen Kurikulum Dalam Perspektif Anti-Radikalisme. Addin,1O(1), 181206. https://doi.org/10.21043/addin.v10i1.1134

Llorent-Bedmar, V., Cobano-Delgado Palma, V. C., \& Navarro-Granados, M. (2020). Islamic religion teacher training in Spain: Implications for preventing islamic-inspired violent radicalism. Teaching and Teacher Education, 95. https://doi.org/10.1016/j.tate.2020.103138

Lubis, D., \& Siregar, H. S. (2020). Bahaya Radikalisme terhadap Moralitas Remaja melalui Teknologi Informasi (Media Sosial). Aplikasia: Jurmal Aplikasi Ilmu-Ilmu Agama, 2o(1), 21-34.

Mahardika, R. E., Assingkily, M. S., \& Kamala, I. (2020). Persepsi Mahasiswa terhadap Radikalisme (Studi Penelitian Deskriptif di UIN Sunan Kalijaga Yogyakarta). Risâlah, Jurnal Pendidikan Dan Studi Islam, 6(1), 1-13. https://doi.org/10.31943/jurnal_risalah.v6i1.123

Mahmud, M. E., \& Zamroni. (2014). Peran Masjid dalam Pengembangan Pendidikan Agama Berwawasan Multikultural Pada Masyarakat. Fenomena, 6(1), 155-170.

Marzuki, Miftahuddin, \& Murdiono, M. (2020). Multicultural education in salaf pesantren and prevention of religious radicalism in Indonesia. Cakrawala Pendidikan, 39(1), 12-25. https://doi.org/10.21831/cp.v39i1.22900

Mundiri, A. (2011). Metodologi Studi Islam: Percikan Pemikiran Tokoh Dalam Membumikan Agama.Jogjakarta: Ar-Ruzz Media.

Mundiri, A., Najiburrahman, \& Muali, C. (2020). Anti radicalism education; amplification of islamic thought and revitalisation of the higher education in indonesia. Proceedings of the International Conference on Industrial Engineering and Operations Management, August, 3802-3814.

Munif, M. (2018). Perguruan Tinggi Berbasis Pesantren: Menggagas Interkoneksi Agama dan Sains. Jurnal Penelitian, 12(1), 137-160. https://doi.org/10.21043/jp.v12i1.4928

Muqoyyidin, A. W. (2013). Deradikalisasi Pendidikan Islam dan Tantangannya di Indonesia. Annual International Conference on Islamic Studies, 8 Nopember, 481-497.

Noorhayati, S. M. (2020). Mekanisme Kultural sebagai Counter-Radikalisme: Mengurai Narasi Terorisme Muslim Sasak di Nusa Tenggara Barat (NTB). AT-TURAS: Jurnal Studi Keislaman, 7(1), 16-29. https://doi.org/10.33650/at-turas.v7i1.1190

Pratiwi, A., \& Asyarotin, E. N. K. (2019). Implementasi literasi budaya dan kewargaan sebagai solusi disinformasi pada generasi millennial di Indonesia. Jurnal Kajian Informasi \& Perpustakaan, 7(1), 65-80.https://doi.org/10.24198/jkip.v7i1.20066

Qomaruzzaman. (2013). Majelis Mujahidin Indonesia (MMI) di Tengah Isu Penerapan Syariat Islam (Studi Analisis Teori Gerakan Sosial). In Right: Jurnal Hak dan Asasi Manusia, 3(1), $43-67$.

Rantung, D. A. (2018). Peran PAK dalam Gereja Untuk Menangkal Radikalisme dan Fundamentalisme Agama di Kalangan Generasi Muda. Jurnal Shanan, 2(1), 1-38.

Rengkung, F., \& Lengkong, J. P. (2020). Pentingnya Revitalisasi Pemahaman Nilai-Nilai Pancasila Untuk Mencegah Mekarnya Radikalisme Pada Generasi Muda. Jurnal Politico, 9(4), 1-8.

Rokhmad, A. (2012). Radikalisme Islam Dan Upaya Deradikalisasi Paham Radikal. Walisongo: Jurnal Penelitian Sosial Keagamaan, 2O(1), 79. https://doi.org/10.21580/ws.20.1.185 
Rozi, S. (2019). Pendidikan Moderasi Islam KH. Asep Saifuddin Chalim; Mencegah Radikalisme Agama dan Mewujudkan Masyarakat Madani Indonesia. Tarbiya Islamia: Jurnal Pendidikan Dan Keislaman, 8(1), 26-43.

Siagian, S. B. U. (2020). Nilai- Nilai Pancasila Dalam Menangani Intoleransi Di Indonesia. Jurnal Teologi Biblika, 5(1), 36-45. https://doi.org/10.48125/jtb.v5i1.23

Solikhun, S. (2021). Relevansi Konsepsi Rahmatan Lil Alamin dengan Keragaman Umat Beragama. Hanifiya : Jurnal Studi Agama-Agama, 4(1), 42-67.

Sudjito, \& Muhaimin, H. (2018). Membudayakan Nilai-Nilai Pancasila Dan Upaya Menangkal Tumbuhnya Radikalisme Di Indonesia. WASKITA: Jurnal Pendidikan Nilai Dan Pembangunan Karakter, 2(1), 1-16. https://doi.org/10.21776/ub.waskita.2018.002.01.1

Suprapto, R. (2014). Deradikalisasi Agama Melalui Pendidikan Multikultural-Inklusiv. Profetika, 15(2), 246-26o. http://journals.ums.ac.id/index.php/profetika/article/viewFile/2001/1412

Syahputra, M. C. (2020). Jihad Santri Millennial Melawan Radikalisme di Era Digital: Studi Gerakan Arus Informasi Santri Nusantara di Media Sosial. Jurnal Islam Nusantara, 4(1), 69-80.

Syatar, A. (2020). Strengthening Religious Moderation In University: Initiation To Universitas Islam Negeri Alauddin Makassar. Kuriositas: Media Komunikasi Sosial Dan Keagamaan, 13(2), 236-248.

Tanjung, I. U. (2018). Studi Komparative Pendirian Negara Khilafah Di Indonesia. Jurnal PenelitianMedanAgama, 9(1), 111-140.

Ulum, M. B., \& Azhari, A. N. (2018). Nilai-nilai Pendidikan Islam dalam Tradisi Ngejot: Konsep Edukasi dalam Membangun Keharmonisan dan Kerukunan Antarumat Beragama Berbasis Kearifan Lokal. FENOMENA: Jurnal Penelitian, 1O(1), 1-26.

Zuhdi, M. H. (2010). Fundamentalisme dan Upaya Deradikalisasi Pemahaman al-Qur'an dan Hadis. RELIGIA, 13(1), 81-102. https://doi.org/10.28918/religia.v13i1.176

Zulfaizah. (2018). Revitalisasi Pendidikan Agama dalam Pembentukan Karakter Peserta Didik di Madrasah. ELEMENTARY, 6(1), 43-62. 